\title{
ROMANTISASI EKONOMI DETERMINISTIK DALAM PROPAGANDA (Telaah Kritis terhadap Eksistensi Gerakan Masyarakat Pro Reklamasi Teluk Benoa)
}

\author{
Ni Luh Nyoman Kebayantini ${ }^{1}$ \\ Nyoman Ayu Sukma Pramestisari, S.Sos ${ }^{2}$ \\ ${ }^{1}$ Dosen Sosiologi Universitas Udayana \\ email:nym_kebayantini@gmail.com \\ ${ }^{2}$ Mahasiswa Magister Sosiologi Universitas Gadjah Mada \\ email: allgtr.asp@gmail.com
}

\begin{abstract}
ABSTRAK
Wacana pembangunan bergaung dengan kuat pada rezim pemerintahan orde baru. Tahun 1980 menjadi titik tonggak keyakinan pemerintah bahwa pembangunan dapat menyelamatkan masyarakat dari keterbelakangan dan kemiskinan. Maka dari itu, proses industrialisasi diberlakukan diberbagai aspek salah satunya adalah industri pariwisata. Bali menjadi salah satu provinsi yang menjadikan industri pariwisata sebagai penyokong kehidupan perekonomian. Dalam perjalanannya perkembangan industri pariwisata dewasa ini menuai pro dan kontra dalam masyarakat sebab pada tataran tertentu masyarakat merasa bahwa proses industrialisasi kerap membawa dampak negatif bagi kehidupan sosial budaya masyarakat dan lingkungan. Dalam tulisan ini kasus reklamasi Teluk Benoa menjadi lokus pembahasan mengingat kelahiran gerakan masyarakat tolak reklamasi yang disusul gerakan masyarakat pendukung reklamasi. Perspektif Jowett dan O’Donnell mengenai propaganda digunakan sebagai pisau analisis terkhusus dalam menelaah gerakan masyarakat pro reklamasi. Hasil analisis berdasarkan elaborasi teori dan data menunjukkan bahwa setidaknya meliputi lima teknik kesukesan penyebaran propaganda yaitu labelling, testimoni dari tokoh terpandang, plain folks dimana meyakinkan khalayak terkait kualitas gagasan sebab terlibat partisipasi dan kepentingan masyarakat luas di dalamnya, pemaparan atas bukti dan fakta hanya yang mendukung pergerakan, bandwagon dimana menginternalisasikan sesuatu sebagai urgensi padahal senyatanya tidak bersifat urgensif.
\end{abstract}

Kata kunci: Pembangunan; Industri; Pariwisata; Reklamasi; Teluk Benoa.

\begin{abstract}
The discourse of development resonates strongly in the Orde Baru regime. The 1980s became a milestone in the government's belief that development can save society from underdevelopment and poverty. Therefore, the industrialization process is applied in various aspects one of which is the tourism industry. Bali became one of the provinces that made the tourism industry as a supporter of economic life. In the course of the development of the tourism industry today reaping the pros and cons in society because at a certain level the community feels that the process of industrialization often brings negative impacts on the socio-cultural life of society also the environment. In this paper the case of the reclamation of the Teluk Benoa becomes a locus of discussion considering the birth of the community movement against reclamation (FORBali) which was followed by a community movement supporting reclamation. Jowett and $O^{\prime}$ Donnell's perspective on propaganda is used as a special analysis knife in examining the pro-reclamation community movement. The results of the analysis based on theoretical and data elaboration show that at least five success techniques for propagating propaganda are labeling, testimonials from respected figures, plain folks, which convince audiences about the quality of ideas because they involve participation and the interests of the wider community in them, the exposure of evidence and facts only that support movement, bandwagon which internalize something as urgency when in fact it is not urgent.
\end{abstract}

Keyword: Development; Industry; Tourism; Reclamation; Benoa Bay 


\section{PENDAHULUAN}

Dilacak secara historis, pembangunan di Indonesia telah masuk ke dalam agenda politik sebagai upaya mengentaskan kemiskinan dan menggiring masyarakat pada kondisi ideal yaitu sejahtera. Bahkan, preferensi terkait pembangunan Indonesia sejak era orde baru sangat kental dipengaruhi oleh liberalisasi pasar. Kajian Globalisasi Kemiskinan dan Ketimpangan berdasarkan International Forum on Globalization (2006) memaparkan pasar bebas menekankan kebebasan setiap individu dengan meminimalisasi intervensi negara atas pasar dengan tiga asas mendunia yaitu deregulasi, privatisasi dan liberalisasi. Termasuk dengan masuknya para investor baik berdagang maupun menanamkan modal melalui saham dalam ranah pembangunan fisik dirasa mampu dalam memenuhi target peningkatan ekonomi. Tendensi peran pasar bebas semakin kuat ketika terjadi penandatanganan Letter of Intent dengan IMF pada tahun 1998.

Trajektori Indonesia membuka diri pada pasar bebas di era orde baru menunjukkan bahwa peran lembaga dunia semakin kuat termasuk mengontrol konsep, arah dan implementasi pembangunan. Bukti konkret pengadopsian paradigma dan konsep pembangunan negara maju oleh Indonesia ialah industrialisasi. Wacana industrialisasi dianggap sebagai jalur akselerasi peningkatan pertumbuhan perekonomian sehingga paska penetapan kebijakan terjadi perubahan mendasar terhadap lajur perekonomian masyarakat (Hadirman, 2017). Industri pariwisata menjadi salah satu jalan meningkatkan perekonomian daerah khususnya melalui penetapan UU Kepariwisataan No. 9 Tahun 1990 yang kini menjadi No. 10 Tahun 2009. Beberapa daerah akhirnya menjadikan industri pariwisata sebagai tonggak pertumbuhan perekonomian termasuk Bali.

Perkembangan industri pariwisata Bali secara signifikan berkembang pesat sejak tahun 1980an terutama Bali selatan dalam konteks pembangunan infrastruktur dan akomodasi penunjang industri pariwisata (Pramestisari, 2019). Pembangunan tersebut meliputi hotel, vila, restauran, resort dan wisata buatan terkhusus daerah Kuta, Nusa Dua, Canggu, Seminyak dan Legian. Menjadi menarik ketika melihat iklim industri pariwisata Bali selatan dewasa ini mengelami kepadatan sehingga muncul wacana pada tahun 2012 untuk melakukan reklamasi Teluk Benoa guna 
mengembangkan industri pariwisata. Selain itu, jika terealisasi reklamasi Teluk Benoa dirasa tepat karena tidak akan mengambil lahan masyarakat di daratan Bali melainkan pemanfaatan kawasan dengan cara revitalisasi (Anggara, 2017). Logika ini secara mendasar dapat saja dikatakan sebagai alternatif solusi bagi pemerintah dalam merespon berbagai kajian dan kritikan terkait permasalahan lahan masyarakat yang menipis akibat pengembangan pariwisata.

Sejalan dengan gempuran wacana reklamasi Teluk Benoa, masyarakat yang tergabung dalam aliansi masyarakat ForBALI mengupayakan pembatalan reklamasi Teluk Benoa secara persuasif hingga represif. Masyarakat yang tergabung dalam gerakan sosial ini berasal dari berbagai kalangan seperti akademisi, seniman, masyarakat adat dan grup musik dan lain sebagainya. Hal ini dikarenakan pandangan kritis masyarakat bahwa rencana reklamasi Teluk Benoa mereduksi partisipasi masyarakat dan hanya mengakomodasi kepentingan oligarki. Dimensi kepentingan oligarki bertolak dari keterlibatan investor tingkat tinggi serta penetapan kebijakan Perpres 51 Tahun 2014 kontroversial tanpa sepengetahuan publik. Polemik penetapan kebijakan terletak pada produksi wacana pemerintah bahwasannya reklamasi dilakukan karena terjadi sedimentasi. Hal tersebut tentu kontradiktif mengingat jika terjadi sedimentasi seharusnya dilakukan upaya pengerukan terhadap wilayah konservasi, namun yang dilakukan justru sebaliknya.

Eksistensi aliansi masyarakat kontra reklamasi ForBALI dewasa ini tidak saja berlawanan dengan para oligarki, melainkan terbelah dengan hadirnya wacana tandingan oleh aliansi masyarakat pro reklamasi. Produksi wacana oleh aliansi masyarakat pro reklamasi meliputi pentingnya revitalisasi kawasan Teluk Benoa sehingga diperlukan reklamasi untuk menyelamatkan nelayan dan biota laut akibat sedimentasi. Kontestasi dua wacana ini menjadi menarik untuk dikaji khususnya kehadiran masyarakat pro reklamasi. Disamping kajian terkait masih minim, kehadiran aliansi ini dirasa menarik sebab menjadi wacana tandingan atas masifnya aksi aliansi masyarakat tolak reklamasi ForBALI. Maka dari itu, tulisan ini akan mengkaji secara lebih kritis dan mendalam terkait eksistensi produksi wacana oleh aliansi masyarakat pro reklamasi. Selanjutnya, perspektif propaganda milik Jowett dan O'Donnell akan digunakan sebagai pisau analisis. Adapun analisis akan 
didukung menggunakan data primer berupa arsip wawancara dengan para aktivis dan data sekunder meliputi kajian terdahulu baik dari buku, jurnal maupun berita yang diperoleh melalui media cetak maupun online.

\section{HASIL DAN PEMBAHASAN}

Bagai dua sisi mata uang, pro kontra dalam sebuah kejadian akan selalu hadir beriringan. Tetapi ketika menyoal sebuah gerakan sosial, terpecahnya suara rakyat akan menjadi boomerang sebab rakyat harus melawan sesama rakyat. Kondisi inilah yang sedang terjadi dalam konteks gerakan sosial aliansi masyarakat tolak reklamasi Teluk Benoa ForBALI. Kehadiran wacana tandingan atas sikap kritis dan perjuangan aliansi masyarakat ForBALI kini memiliki oposisi baru selain oligarki, yaitu masyarakat aliansi pro reklamasi. Serupa dengan ForBALI, aliansi masyarakat pro reklamasi juga melakukan berbagai aksi demonstrasi dalam konteks menggugat pemerintah sesegera mungkin melangsungkan proyek reklamasi. Maka dari itu, sebelum menganalisa relevansi dimensi propaganda dalam aksi masyarakat pro reklamasi, penting bagi penulis untuk memberikan gambaran singkat mengenai dinamika eksistensi kedua gerakan sosial ini.

Rekam jejak perjuangan masyarakat pro reklamasi hadir paska gerakan masyarakat kontra reklamasi kian massif. Pada tahun 2012 mencuat kebijakan pemerintah melakukan reklamasi di kawasan konservasi Teluk Benoa melalui Perpres 51 Tahun 2014 dengan mengubah status konservasi menjadi zona penyangga atau kawasan pemanfaatan umum. Paska penerbitan Perpres, PT. Tirta Wahana Bali Internasional (PT. TWBI) mengantongi izin lokasi reklamasi dari menteri kelautan dan perikanan seluas 700 Hektar. Dilain sisi, masyarakat merasakan hal mengganjal mengenai produksi wacana pemerintah bahwasannya reklamasi dilakukan karena terjadi sedimentasi. Hal tersebut tentu kontradiktif mengingat jika terjadi sedimentasi seharusnya dilakukan upaya pengerukan terhadap wilayah konservasi, namun yang dilakukan justru sebaliknya.

Di samping tindakan kontradiktif melalui regulasi, Universitas Udayana Denpasar dalam konferensi pers menyatakan bahwa hasil dari studi kelayakan rencana reklamasi Teluk Benoa dinyatakan tidak layak baik dari aspek teknis, 
lingkungan, sosial budaya dan ekonomi finansial (ForBALI, 2013). Meskipun hasil studi kelayakan telah terbit, proyek reklamasi tetap berjalan. Berbagai paradoks mengakibatkan masyarakat merasa bahwa aspirasi mereka tidak terakomodasi dengan baik. Pasalnya, sedari awal masyarakat merasa upaya negosiasi melalui komunikasi terkait rencana reklamasi tidak mendapat respon memadai. Bahkan terdapat indikasi dalam proses perencanaan dan pengembangan hanya melibatkan aliansi pro reklamasi.

Dalam setiap kesempatan, pemerintah dan investor akan menyatakan bahwa urgensi reklamasi merupakan wujud nyata untuk mengembangkan industri pariwisata Bali termasuk demi kepentingan masyarakat Bali. Apabila reklamasi terealisasi maka akan terjadi proses industrialisasi termasuk ketersediaan lapangan kerja, menyerap pengangguran dalam jumlah besar dan peningkatan pertumbuhan ekonomi daerah serta pusat akibat devisa (Wardana, 2017). Di lain sisi, perwakilan aliansi masyarakat penolak reklamasi tetap beranggapan bahwa terealisasinya reklamasi hanya akan membawa dampak buruk lebih besar seperti hilangnya fungsi konservasi, rentan akan bencana alam dan banjir, terumbu karang rusak, abrasi dan pembangunan tak berimbang. Keteguhan kedua belah pihak dengan paradigma masing-masing inilah yang mengakibatkan ketegangan sosial tanpa henti.

Pada tahun 2014, terdapat desakan untuk menyegerakan reklamasi melalui aliansi masyarakat ForsBALI dengan produksi wacana dukung revitalisasi. Perjuangan aliansi masyarakat ini serupa dengan ForBALI seperti aksi hingga pemasangan baligho. Pandangan mereka bahwa proyek reklamasi akan mampu menurunkan angka pengangguran, memperbaiki kondisi perekonomian masyarakat Bali dan menyelamatkan wilayah konservasi (Sukiswanti, 2014). Mereka juga menganggap bahwa gerakan ForBALI hanya menghambat perkembangan industri pariwisata yang sesungguhnya dapat dimanfaatkan ditengah himpitan permasalahan hidup masyarakat. Aliansi masyarakat pro reklamasi mendukung secara penuh melalui pandangan bahwa kondisi alam tidak berpihak pada nelayan sebab sedimentasi kawasan Teluk Benoa. Upaya paling tepat menghadapi permasalahan ini ialah melakukan reklamasi dan investor wajib memfasilitasi 
nelayan dengan tempat budidaya seperti kerang, kepiting, rumput laut dengan biaya ditanggung investor.

Masyarakat pro reklamasi melalui berbagai kajian menyampaikan bahwa proyek reklamasi akan menjadi ramah lingkungan. Hal ini dikarenakan selama proyek berlangsung akan dilakukan pemasangan silk protektor untuk membatasi area pembangunan dan jalur nelayan guna menjaga kebersihan air dan tumbuhan laut. Dimana seluruh argumen disebarkan melalui berbagai media, baik cetak, online hingga aksi demonstrasi. Aksi April 2015 menjadi salah satu aksi besar massa mendesak pemerintah DPRD Bali dan Gubernur untuk segera melakukan proyek revitalisasi dengan tujuh alasan diantaranya mampu mencegah banjir, menambah ruang hijau, meningkatkan aktivitas sosial, budaya dan ekonomi, memulihkan wilayah konservasi Pulau Pudut, melindungi mangrove dan meningkatkan kesejahteraan masyarakat (Winarno, 2015).

Penting untuk diperhatikan bahwa komposisi masyarakat pro reklamasi berasal dari setidaknya 10 organisasi kemasyarakatan yang tergabung dalam Aliansi Masyarakat Peduli Pariwisata dan Budaya Bali. Di samping itu terdapat beberapa tokoh publik, misalnya I Made Mangku selaku Ketua Sekertariat Kerja Pelestari dan Penyelamatan Linkungan Hidup dan, Ranten selaku ketua adat se-Bali dan Made Derik selaku aktivis masyarakat Bali. Tiga tokoh masyarakat tersebut terkenal sangat lantang menyuarakan revitalisasi melalui reklamasi. Memperhatikan komposisi aliansi masyarakt pro reklamasi nampak serupa dengan ForBALI, dimana memposisikan diri menjembatani aspirasi masyarakat dalam konteks reklamasi Teluk Benoa dilengkapi berbagai kajian dan dukungan para elit, hanya saja mengantongi basis solidaritas berlawanan yaitu mendukung dan menolak proyek reklamasi.

Pemaparan realitas mengenai pro kontra reklamasi Teluk Benoa di atas berdasarkan terbelahnya respon masyarakat menunjukkan bahwa sebuah fakta menarik. Gejolak sosial antara kedua kubu sesungguhnya merupakan refleksi atas sebuah perjuangan untuk memenangkan kuasa atas arah pembangunan. Bertolak dari realita tersebut maka Perspektif Propaganda milik Jowett dan O'Donnell menjadi relevan. Perlu penulis tekankan bahwa fokus kajian penulis ialah aliansi 
masyarakat pro reklamasi dengan basis analisis pola penyebaran wacana kepada publik yang mencuat paska gerakan ForBALI semakin masif pada tahun 2014. Maka dari itu, relevansi antara teori dan realitas paling mendasar ialah terdapat kepentingan bertolakbelakang dengan ForBALI namun penting untuk dikaji lebih lanjut mengenai kemurnian basis gerakan.

Respon aliansi masyarakat pro reklamasi terhadap aliansi masyarakat kontra reklamasi bila ditelisik secara kritis merupakan bentuk propaganda tandingan. Ketika penggaungan berwajah produksi dan reproduksi wacana terkait implikasi positif dari realisasi mega proyek reklamasi dilakukan maka upaya propaganda telah dimulai (Razaka, 2017). Melempar wacana tandingan menjadikan berbagai argumen aliansi masyarakat ForBALI terbantahkan terutama terkait proses penetapan kebijakan cenderung mereduksi partisipasi masyarakat. Hal ini dikarenakan pergerakan masyarakat pro reklamasi mengidentifikasikan diri sebagai bagian dari masyarakat pendukung atas segala bentuk rasionalitas dibalik pembangunan. Indikasi kesan pergerakan sebagai bentuk propaganda terletak ketika intensitas upaya komunikasi semakin gencar dengan menyebarkan simbolsimbol tertentu seperti baligho dengan konsistensi tulisan Dukung Revitalisasi Melalui Reklamasi.

Menjadi menarik ketika sebagian besar dari aktivis ForBALI dan masyarakat kontra reklamasi memaparkan terbentuknya aliansi pro reklamasi merupakan upaya mendistraksi pandangan masyarakat terhadap kepentingan oligarki. Pergerakan semu dengan meng-atas nama-kan masyarakat pendukung reklamasi semakin kuat ketika proses penyebaran wacana menekankan unsur mencintai dan membenci. Kondisi ini bertolak dari penyebaran isu mengenai pentingnya reklamasi untuk menyelamatkan masyarakat secara sosio kultural termasuk ekonomi dan memandang pergerakan ForBALI merupakan kajian kritis penghalang kemajuan masyarakat (Diputra, 2014). Dengan mengedepankan agenda "realistis" dalam propaganda secara implisit pergerakan ini ingin meredam pandangan kritis dengan spirit mengontrol opini publik agar tetap berada pada kerangka pembangunan awal bersendikan neo liberalisme. 
Upaya pergerakan aliansi masyarakat pro reklamasi sejalan dengan pandangan Jowett dan O'Donnell, dimana propaganda dilakukan untuk manajemen sikap kolektif dengan menggunakan simbol yang signifikan dibandingkan kekerasan, penyuapan dan pemboikotan (Jowett \& O'Donnell, 2012). Kondisi ini ditunjukkan dengan kelahiran aliansi masyarakat pro reklamasi paska terjadi penyerangan terhadap aktivis ForBALI ketika melakukan aksi, percobaan penyuapan terhadap para aktivis berpengaruh dan kebuntuan negosiasi antara DPRD Provinsi, Gubernur, Investor dengan aliansi ForBALI. Spirit emansipatoris berlandaskan integritas tinggi menjadikan aliansi masyarakat ForBALI secara gamblang menyebarkan berbagai bentuk intimidasi oleh para oligarki baik melalui media sosial maupun aksi turun ke jalan. Pada tataran ini, tesis Jowett dan O’Donnell menjadi relevan tatkala propaganda digencarkan untuk manajemen sikap kolektif dengan menggunakan simbol yang signifikan daripada kekerasan, penyuapan dan pemboikotan. Simbol dalam konteks ini meliputi identitas "pergerakan rakyat" yang dibangun dalam wacana masyarakat aliansi pro reklamasi. Di lain sisi, bentuk komunikasi sosial lain tersebar dalam bentuk baligho, aksi, poster dan berita di media massa.

Propaganda dalam kacamata Jowett dan O'Donnell (2012) memiliki tujuan mempengaruhi sikap dan tingkah laku dari kelompok sasaran. Dimana propagandis berupaya mengolah target sasaran untuk menerima pesan dan menjadikan pesan sebagai kenyataan dalam tindakan. Ketika posisi pergerakan masyarakt pro reklamasi telah teridentifikasikan sebagai pergerakan semu, maka kelompok sasaran ialah simpati publik secara umum dalam mencerna perang wacana antara dua kubu pro dan kontra. Memecah opini publik menjadi tujuan utama guna menyusupi ideologi melalui penyebaran wacana ideal. Ideologi dalam konteks ini ialah kehadiran reklamasi sebagai "dewi penyelamat" atas permasalahan sosial ekonomi masyarakat Bali melalui berbagai kajian empiris berpondasikan rasionalitas. Artinya, ada upaya menggiring perspektif masyarakat dalam memandang praktek pembangunan bersendikan sistem neoliberal menjadi suatu kewajaran serta memandang tindakan kritis sebagai penghambat kemajuan. 
Memahami pergerakan semu masyarakat pro reklamasi sebagai propaganda maka penting untuk mengidentifikasikan jenis propaganda ini. Kontekstualisasi eksistensi aliansi pro reklamasi dengan jenis propaganda menjadi menarik sebab pada ranah awam akan nampak sebagai propaganda putih. Hal ini terefleksikan dari sumber propaganda jelas dan terbuka yaitu dari masyarakat dan tokoh masyarakat. Selanjutnya, informasi bersifat akurat dengan mengedepankan berbagai data yang bersifat rasional dan dapat dipertanggungjawabkan dapat dilihat dari berbagai kajian terbitan peneliti ternama baik dari segi sosial, ekonomi, budaya maupun lingkungan (Razaka, 2017). Menariknya, pesan utama dalam propaganda ini secara tersurat menginginkan kelancaran pembangunan demi meningkatkan taraf hidup masyarakat Bali dan memandang gerakan sosial kontra reklamasi sebagai penghambat kemajuan perekonomian dari persaingan global.

Dilain sisi, secara kritis propaganda pro reklamasi secara signifikan cenderung merupakan propaganda hitam. Berbagai realita pada analisis propaganda putih hanya bagian dari pencitraan sebab seperti analisis di atas, terdapat indikasi pergerakan ini dirancang dan dibentuk oleh oknum oligarki demi melancarkan proyek reklamasi bersendikan prinsip neoliberal. Sebagaimana propaganda hitam dilancarkan dengan menyembunyikan identitas aktor utama dan mengaku berasal dari pihak lain. Penyamaran identitas dilakukan sebab informasi disampaikan penuh dengan distorsi (Jowett \& O'Donnell, 2012). Menariknya, praktik propaganda ini mencapai kesuksesan dengan melakukan pendekatan secara budaya, sosial, politik dan psikologi khususnya masyarakat Bali.

"Ah itu sebenarnya anteg TW. Biar terpecah aja fokus masyarakat kalau melihat perjuangan ForBALI.”- (AN, 2019)

Dalam praktiknya, propaganda dalam wacana masyarakat pro reklamasi mengantongi setidaknya lima teknik kesuksesan. Pertama, labelling dimana proyek reklamasi dipaparkan sebagai gagasan terbaik dalam menghadapi berbagai permasalahan sedangkan ForBALI hanyalah segerombolan masyarakat idealis tanpa berpikir realistis terutama peningkatan pertumbuhan perekonomian. Kedua, 
testimoni dari tokoh terpandang sebagai seorang profesional memberikan pendapat yang terekognisi oleh bidang ilmunya seperti Ranten, I Made Mangku dan Derik. Ketiga, plain folks dimana meyakinkan khalayak terkait kualitas gagasan sebab terlibat partisipasi dan kepentingan masyarakat luas di dalamnya. Hal inilah yang menjadi poros utama gencaran propaganda masyarakat pro reklamasi. Keempat, card stacking meliputi pemaparan atas bukti dan fakta hanya yang mendukung pergerakan. Hal ini dapat dilihat bahwa berbagai kajian kritis terkait implikasi negatif industri pariwisata di Bali samasekali tidak dilibatkan. Kelima, bandwagon dimana menginternalisasikan sesuatu sebagai urgensi padahal senyatanya tidak bersifat urgensif. Hal inilah terefleksikan dari bagaimana wacana reklamasi hadir paska penetapan program Masterplan Percepatan dan Perluasan Pembangunan Ekonomi Indonesia yang menetapkan Bali salah satu daerah penyokong melalui pengembangan industri pariwisata (Suryani, 2017). Reklamasi tentu menjadi urgensif apabila dilihat dari segi kepentingan pertumbuhan perekonomian dan akumulasi kapital para investor.

"Iya orang kemarin itu loh si TW udah bagi-bagi amplop biar lolos proyek

$$
\begin{aligned}
& \text { reklamasi" } \\
& -(N N, 2019)
\end{aligned}
$$

"Berbagai upaya pelancaran proyek sudah bisa dilihat kok, berita di televisi aja gak pernah memberitakan perjuangan ForBALI kan." - (NN, 2019)

Analisis di atas menguatkan peran oligarki dalam mengupayakan mega proyek reklamasi melalui berbagai cara termasuk propaganda. Upaya tersebut dilakukan melalui produksi dan reproduksi wacana atas nama kepentingan rakyat serta dilakukan oleh rakyat. Pandangan ini semakin mempertegas benang merah peran sistem neoliberalisme dimana spirit utama untuk melakukan akumulasi kapital dan menjadikan apapun sebagai alat produksi sekalipun termasuk diri mereka sendiri, sehingga tidak jarang berujung pada eksploitasi baik tenaga, waktu dan pikiran (Wibowo \& Wahono, 2003). Pada akhirnya, propaganda masyarakat pro reklamasi hanyalah instrumen bagi para oligarki demi kepentingan ekonomi 
semata. Bahkan kepentingan ekonomipun hanya meliputi segelintir pihak. Sekalipun masyarakat merasakan beberapa manfaat, risiko atas iklim industri pariwisata yang cenderung memarjinalkan harus dengan rela ditanggung. Hal ini bertolak dari kajian bahwa perjuangan ForBALI melawan reklamasi Teluk Benoa sesungguhnya merupakan momentum dalam meluapkan kritik atas iklim industri pariwisata di Bali yang kian menggerus masyarakat kelas bawah akibat implementasi tiga pondasi utama neoliberalm yaitu deregulasi, liberalisasi dan privatisasi.

\section{KESIMPULAN}

Trajektori konsep pembangunan Indonesia gencar dilakukan sejak tahun 1980an guna meningkatkan pertumbuhan perekonomian sebagai negara berkambang. Salah satu upaya ialah melalui industrialisasi diberbagai sektor termasuk industri pariwisata. Melalui UU Kepariwisataan No. 9 Tahun 1990, Bali menjadi satu dari beberapa daerah dengan menetapkan pariwisata sebagai penyokong perekonomian. Hal ini secara signifikan berpengaruh terhadap transformasi masyarakat secara sosial budaya seperti marjinalisasi masyarakat kelas bawah, privatisasi ruang publik dan komodifikasi budaya. Kepadatan sektor pariwisata daerah Bali selatan dewasa ini akhirnya memicu wacana reklamasi Teluk Benoa sekaligus mendukung agenda pemerintah dalam kebijakan proyek MP3EI dengan target pendapatan Indonesia tahun 2025 sejumlah U\$ 16.000.

Bersamaan dengan agenda pemerintah, terdapat aliansi masyarakat tolak reklamasi yaitu ForBALI. Pada tataran ini ForBALI menggunakan wacana reklamasi sebagai momentum mengkritik iklim pariwisata Bali serta indikasi bahwa proyek ini hanya mengakomodasi kepentingan oligarki pada sistem neoliberal. Bertepatan dengan semakin massifnya pergerakan masyarakat ForBALI, pada tahun 2014 muncul aliansi masyarakat pro reklamasi. Secara implisit agenda pergerakan ini mendesak pemerintah untuk segera melakukan revitalisasi dengan reklamasi guna menyelamatkan biota laut dan nelayan dari sedimentasi serta akan mampu menyerap tenaga kerja sekaligus mengembangkan potensi pariwisata Bali. Tetapi apabila dianalisis menggunakan teori propaganda milik Jowett dan 
O’Donnell sesungguhnya aliansi masyarakat pro reklamasi merupakan propaganda hitam bentukan oligarki guna melancarkan aksi reklamasi. Hal ini terlihat dari pola persebaran wacana, upaya menyisipkan ideologi bahwa reklamasi merupakan jawaban terbaik atas permasalahan sosial serta eksistensi sikap kritis ForBALI hanyalah penghalang kemajuan Bali. Pergerakan ini menjadi sulit untuk dikenali secara implisit, sebab secara eksplisit mengatasnamakan rakyat, menggunakan testimoni dari tokoh publik serta mereduksi berbagai pemikiran kritis melalui romantisasi fakta pendukung. Maka dari itu, propaganda dalam tataran ini merupakan instrumen dari para oligarki guna mengakumulasikan profit dengan memecah kesadaran kritis masyarakat dengan menjadikan ekonomi deterministik ala neoliberal sebagai sesuatu yang lumrah.

\section{Referensi}

Anggara, V. T. (2017). Gerakan Forum Rakyat Bali Tolak Reklamasi Dalam Penolakan Reklamasi Teluk Benoa Nusa Dua Bali. Universitas Airlangga.

Diputra, R. (2014). Pro Kontra Reklamasi Teluk Benoa. Denpasar: okenews. $\begin{array}{llll}\text { diakses } & \text { pada } & 14 & \text { Desember }\end{array}$ https://news.okezone.com/read/2014/10/04/340/1048165/pro-kontrareklamasi-teluk-benoa.

ForBALI. (2013). Mengapa Kami Menolak. Retrieved from ForBali.org: https://www.forbali.org/id/mengapa-kami-menolak/

ForBALI. (2019). Spektakuler! ForBALI Tumpuk Baligho DPRD Dengan Gambar Sangut. diakses pada tanggal 26 September 2019. https://www.forbali.org/id/spektakuler-forbali-tumpuk-baliho-dprddengan-gambar-sangut/.

Hadirman, F. (2017). Dalam Moncong Oligarki. Yogyakarta: Kanisius .

Jowett, G. S., \& O'Donnell, V. (2012). Propaganda and Persuasion. USA: SAGE.

Peraturan Presiden No. 51 Tahun 2014 Tentang Perubahan Atas Peraturan Presiden No 45 Tahun 2011 Tentang Rencana Tata Ruang Kawasan Perkotaan SARBAGITA

Pramestisari, N. A. (2019). Desa Dalam Pusaran Industri Pariwisata. Yogyakarta: SKRIPSI.

Razaka, S. A. (2017). Propaganda di Media Online Analisis Isi Pemberitaan Donald Trump pada BBC Indonesia.com. Yogyakarta: SKRIPSI .

Sukiswanti, P. (2014). Sejumlah Ormas Bali Dukung Revitalisasi Teluk Benoa. Bali dan Nusa Tenggara: Indonews.com. 
Suryani, L. (2017). Ternyata Ada Rencana Bisnis Wisata Tol di Atas Teluk Benoa. Mangabay: Diakses pada $27 \quad$ September 2019. http://www.mongabay.co.id/2017/02/02/ternyata-ada-rencana-bisniswisatatol- di-atas-teluk-benoa/.

UU Kepariwisataan No. 9 Tahun 1990

Wardana, A. (2017). Neoliberalisasi Kawasan Perairan Teluk Benoa: Sebuah Catatan Kritis atas Praksis Perlawanan di Bali. Wacana Jurnal Transformasi Sosial, 55-90.

Wibowo, I., \& Wahono, F. (2003). Neoliberalisme. Yogyakarta: CPRC.

Winarno, H. H. (2015). Demo, Massa Pro Reklamasi Teluk Beoa Bertemu Dengan DPRD Bali. Denpasar: merdeka.com, diakses pada 17 Desember 2019. https://www.merdeka.com/peristiwa/demo-massa-pro-reklamasi-telukbenoa-bertemu-dengan-dprd-bali.html. 